\title{
SELECTED PROBLEMS OF APPLYING THE LAW IN ADAPTATION AND MODERNIZATION OF BUILDINGS IN POLAND
}

\author{
Wojciech KORBEL ${ }^{1}$, \\ Cracow University of Technology, Kraków, Poland
}

\begin{abstract}
Chosen problems of law implementation in the contemporary process of building's modernization in Poland.

One of the major problems in the contemporary process of building's modernization in Poland is the pluralism of different interpretations of chosen legal terms, existing in the contemporary building code. Incorrect interpretation, results in the incorrect application to the authorities for the proper building permit and as the effect, it causes the lost of time and money. The article tries to identify some of these problems and seeks the solution to solve them, through the evolutionary method of building law creation.
\end{abstract}

Keywords: law interpretation, building objects' adaptation and modernization process.

\section{INTRODUCTION}

One of the key issues in the process of adaptation and modernization of buildings is the proper legal classification of the planned works and the ability to apply adequate procedures for their approval by the suitable administration body. The inability to use the law in this area or the improper interpretation of the law (or different from the official one, used by the authorities granting the consent - tacit or in the form of an administrative decision), results in the loss of precious time and significant financial resources. This work shall, therefore, refer to the issue of application and creation of the law concerning the

\footnotetext{
${ }^{1}$ Corresponding author: Cracow University of Technology, Faculty of Architecture, Podchorążych st 1, 30-084 Kraków, Poland, e-mail: pracowniakorbel@gmail.com, tel. + 4812628243
} 
adaptation and modernization of buildings in Poland. The carried out studies will investigate the question of any necessary changes in the applicable law and the directions of new legislation for the process of adaptation and modernization of buildings through a comparative analysis of the selected provisions of the law and the ways of their interpretation in the practice of judicial decisions. The issues discussed at this work, due to the need of its brevity, have been fundamentally limited to a selected issue of the Construction Law [1], and to the changes in this legal act which are currently being planned to be introduced by the Government.

\section{SELECTED PROBLEMS OF APPLICATION OF THE CONSTRUCTION LAW IN THE PROCESS OF ADAPTATION AND MODERNIZATION OF BUILDINGS}

In accordance with the general principle enshrined in Art. 28 of the Construction Law, construction works can start only on the basis of a final decision on the construction permit (CP), subject to Articles 29-31. The key issue here is Art. 29 constituting a catalogue of works that do not require an administrative decision, the implementation of which is possible only after a prior notification of intended works or without the notification, as provided by Articles 30 and 31. To present the issues in question, the author selected and analysed two examples of the difficulties in applying the provisions of the existing catalogue of works that are excluded by Article 29 from the rule mentioned in the introduction part.

\subsection{Examples of problems of legal classification of selected adaptation and modernization works in the context of the provisions of the Construction Law}

The first example of the problems of adaptation and modernization of buildings, in the context of the provisions of art. 28 and 29 of the Construction Law, is the issue of the development of internal installations in a building facility. It refers to the construction works related to the extension of the water supply, sewerage, electricity, ventilation, heating or gas installations, both inside the building and outside it, on the owner's premises. The notion of a building expansion included in the definition of "construction" has not been clarified by the legislature, therefore it may, in some cases, be difficult to distinguish from 
a reconstruction referred to in Article 3 of the Law. ${ }^{2}$. It is also worth noting that in the catalogue of works which do not require a decision of $\mathrm{CP}$, contained in Art. 29, there are currently no provisions concerning the expansion of a building or a construction appliance. If, therefore, the nature of these works was not contained in Art. 29, it consistently can be presumed that these works, in accordance with the general standard resulting from Art. 28, could be commenced only after obtaining the construction permit. This opinion, however, is not always reflected in the decisions of the administrative courts.

Provincial Administrative Court in Kraków issued a judgement of 13 April 2012, reflecting somewhat the court's wishful thinking, stating: "Although mounting of an auxiliary electric socket or installing of an extra light in a room will expand the internal electricity installation, and thus its reconstruction, but it would be completely irrational to require a Construction Permit for such works"[2].

In another judgement of 31 October 2008, the same Provincial Administrative Court conditioned the obligation of the building permit on the qualification of the works (expansion of the installation) as the reconstruction of a building (which included the installation) stating that "if such works do not result in any changes in the performance or technical parameters of the building facility, with the exception of specific parameters such as: volume, area, height, length, width or number of storeys, they are not works, referred to in Article 3 and Article point. 28-30" [3].

These not very obvious interpretations expressed by courts resulted in the fact that while issuing the decision, the officials linked both activities, i.e. the expansion of internal installations and the reconstruction of a building that contains the installation. Stating a priori that in the case of expansion of installation, neither technical parameters nor the utility of the object are changed, the courts ruled out the legal classification of a building expansion as a reconstruction, thus admitting that these works neither require permit nor the notification.

Another example of the problems of adaptation and modernization of buildings, is the issue of constructing new separation walls in the existing buildings and thus forming new premises. As in the case of internal installations, also this kind of work is not mentioned by provisions of Art. 29 of the Construction Law, which may indicate that these works require a decision for the construction permit. However, the court's case law in this respect is similar to the previously discussed.

\footnotetext{
${ }^{2}$ The term "construction" also understood as "extension" or "superstructure" of a building and "reconstruction", according to the provisions of art. 3 p.6 and p.7a Act of 7 July 1994 Construction Law
} 
In the judgement of the Provincial Administrative Court based in Gliwice of 30 November 2007, the court stated that "in contrast to the works in the main walls (...), building a partition wall inside a building, forging a hole in it or moving or removing it can not be classified as a reconstruction of a building" [4]. Similarly, the Provincial Administrative Court in Gdańsk in its judgement of 10 October 2012 stated that the work comprising the establishment of partitions "cannot be understood neither as construction works, nor assembly works, nor repair (defined as restoration of the original condition), nor finally demolition" and that these works can not be classified as reconstruction of an existing building since "they change only the internal appearance of the premises, in no way do they change the actual operational or technical parameters of the whole building, and do not affect its volume, building area, height, length, width, number of floors etc." [5].

It is worth noting that the statutory definition of construction works contained in Art. 3, p.7 of the Act, applies only to the construction, and works involving reconstruction, installation, renovation or demolition of a building and not a part of it. So, we can conclude that erecting partition walls with the use of building materials in an existing building can not be called, under the Act, as the construction of these walls. In addition, if we consider that as a result of their erection there is no change in the performance or technical parameters of the existing building, the activities cannot be considered as the reconstruction of the facility, and the records of cited judgements have to be considered valid. However, the problem is that each newly erected partition affects the size of the separated premises, and so it changes, to a lesser or greater extent, operational or technical parameters of the entire object, (just as in the case of expansion of installations) for example by changing the size of the property, the communication space, or the number of its potential users, etc.

Thus, the courts' refusals to regard the erection of partition walls or the installation expansion as reconstruction processes, impose a relativistic way of legal assessment of the problem, difficult to accept by designers expecting unambiguous legal interpretations of the design process. 


\subsection{The procedure of isolation of independent apartments, as an example of insufficient instruments of legal control of a construction ompliant with the intended use of land included in the decision on Development Conditions ${ }^{3}$ or Local Spatial Development Plans (LDP) ${ }^{4}$}

The issue of isolation of independent apartments is subject to the Act on the ownership of premises [6]. It is, however, strongly connected with the execution of construction works in a building facility and with the above described issue of the interpretation of Articles 3,28 and 29 of the Construction Law. Therefore, it also constitutes an important subject of this analysis.

The separation of a premise takes place at the request of its owner, who shall submit a project of the newly formed apartment, together with the appurtenant rooms, to the District Governor (Starosta). The project should be drawn up by a person authorized pursuant to the provisions of the Law on Ownership of Premises. ${ }^{5}$. The authority issues the appropriate certificate confirming the independence of the premises. This certificate may constitute, subsequently, the legal basis for the sale of the real estate [7]. It is also important that the applicant does not have, in any way, to prove the lawfulness of the work, which resulted in the creation of an independent flat. A person authorized to draft a separation plan, refers only to the existing situation, and the administration has no right to demand, in the process of issuing the certificate, any formal legal documents, other than those mentioned above [8]. This opinion is confirmed by case law. According to the judgement of the Supreme Administrative Court of 8 February 2012 "when issuing a certificate of independence of the premises there is no basis for the application of the criteria under the Act - Construction Law and the regulations implementing that law" [9], and it is only the Civil Code which constitutes the distinct rules governing the issue of ownership of premises.

But since the separation of independent premises is not subject to the Construction Law provisions, and the erection of partition walls can be easily recognized as works not subject to any form of approval by architecturalconstruction authorities, it is even more advisable it to put the question of the validity of the position of the judicial authorities on the development of installations and the erection of walls, described in point 2.1.

\footnotetext{
${ }^{3}$ The decision on the conditions of plot development within the meaning of Art. 4 paragraph 2 of the Act of 27 March 2003 on Planning and Spatial Development

${ }^{4}$ Local Development Plan within the meaning of Art. 4 paragraph 1 of the Act of 27 March 2003 on Planning and Spatial Development

${ }^{5}$ rinciples of preparation of the documentation necessary for the separation of independent premises within the meaning of Art. 2 paragraph. 1 - 6 of the Act of 24 June 1994 on Ownership of Premises
} 
If a potential investor realizes, in accordance with the decision on the conditions of plot development, a single-family building consisting of two apartments and starts to use it in accordance with the law, and if then, through the erection of additional partition walls, separates another independent premises, he/she will, de facto, realize a multifamily building, contrary to the original decision of the conditions of plot development. Admittedly, in the already cited judgement of Gdańsk Provincial Administrative Court of 2012, the court noted that the building permit will not be required "if the partition wall (...) does not result in the spatial separation of independent premises which are the subject of separate property", however, making the legalization of work subject to the alleged purpose, for which the planned works would serve in the future, seems to result in the excessively complex construction process. To make matters worse, this relativism deprives the authorities of the control over the implementation of investments run by individual investors, which are frequently inconsistent with the purposes determined in the local spatial development plan and determined in the decision on the conditions of plot development or the Local Development Plan.

\section{THE PROBLEMS PRESENTED IN THE CONTEXT OF THE CONTEMPORARY TRENDS OF LAW CHANGES}

The above-described problems are integrally linked to the quality of new laws and the ongoing work on the draft of the Code on Architecture and Construction (KBU in Polish) [10] and the amendment of the Construction Law Act [11]. Referring to the described problems (of partition wall erection), the project of the Code (KBU) proposes, through its provisions of Art. 212 and Art. 255, § 2, a mode "the reconstruction of a building" implemented through the notification of construction works requiring the administration's tacit consent. The problem of the expansion of internal installation, and the question of separation of independent premises, have not yet been recognized in the provisions of the draft of the Code. The Codification Commission, at its meeting on September 10,2014 , recognised the problem of misusing the transformation of a singlefamily house into a multi-family house, by separating a large number of new, independent premises. However, there is no binding proposal for legal solutions to this problem in the minutes of the meeting [12].

In parallel with the codification work, the Parliament is working on the government bill amending the Act - Construction Law and some other acts. The original project, according to the government's submission of 26 August 2014, assumed only (via added to Art. 29, paragraph 2, point 1a), the possibility of 
reconstruction of single-family dwellings, after obtaining the tacit consent of the authority for the notified works.

The Parliamentary Subcommittee added, in its meeting in December 2014, the construction permit will not be required for the works involving installations assembly and the reconstruction of all buildings mentioned in art. 29 paragraph 1 , as well as the renovation and reconstruction of construction appliances, in addition to the already mentioned reconstruction of single-family dwellings (unless it increases its area of influence). In addition, only the reconstruction of single-family residential buildings would require obtaining tacit consent of administration [13].

The changes, proposed by the Parliamentary Subcommittee, extended the scope of works that do not require the Construction Permit. Construction, expansion or reconstruction of installations, according to the proposed changes do not require even notification. The changes do not refer, however, to all the issues raised in the work. It is still unclear whether construction of partition walls constitutes a reconstruction of the building (then it would require notification or construction permit, depending on the type of building) or whether, according to the court decisions, the issue still depends on the effects which may arise in the future and caused by the erection of these partition walls. The changes in the law also do not meet the expectations as to solving the issue of separating new, independent premises, without checking their compliance with the intended use of land resulting from the local development plan or a decision on the conditions of plot development .

\section{SUMMARY AND CONCLUSIONS}

If the implementation of internal installations is possible without any form of administrative consent, which may be the case after the amendment of the Construction Law Act, one of essential legal ambiguities, described in the work, will cease. However, the issue of the erection of partition walls in buildings will still require clarification, because in spite of changes in the law, the legal classification of these works will remain ambiguous. Their implementation has always (even in a small degree) caused changes in technical and performance parameters, and this should result in the fact that these works should be classified as reconstruction. Administrative courts, however, do not always agree with this position, which indicates the need for a systemic solution to the problem. It may be achieved, for example, by adding a definition of "reconstruction of the building" understood as the realization (within the building) of any works using construction materials, which is not refurbishment or construction. 
In relation to the separation of independent premises, the described problem should be solved in two ways. On the one hand, the Construction Law and the Law on Spatial Planning and Development [14] should be supplemented by provisions requiring the construction permit, issued in accordance with the local development plan or with the decision of the conditions of the plot development before the separation of the premises. On the other hand, it seems necessary to amend the Law on ownership of premises, enabling the authority issuing the relevant certificate to verify the compliance of the proposed separation with the provisions of the Construction Law.

Generally, there is a profound need for a detailed inventory of the problems arising from a variety of interpretations of the provisions of laws. The elimination of these problems may be possible by the evolutionary changes of the law, by narrowing the possibilities of diverse interpretation and standardization of methods of its use. It is also worth considering whether the introduction of an institution issuing binding interpretations of the law, e.g. the Chief Inspector of Construction Supervision, could help solve the problem. At the moment, he/she gives non-binding legal interpretations of the provisions. Against the background of various judgements, the need to elaborate the practice of good application of the law through the development of explicit legislative measures and the minimization of its diverse interpretations is urgent.

\section{REFERENCES}

1. Ustawa z dnia 7 lipca 1994 Prawo budowlane, Dz. U. z 2010 r., Nr 243 poz.1623 ze zmianami.

2. II SA/Kr 193/12 - Wyrok WSA w Krakowie z 2012-04-13, publikacja internetowa.: http://www.orzeczenia-nsa.pl/wyrok/ii-sa-kr-193

12/rozbiorka_budowli_lub_innego_obiektu_budowlanego_dokonanie_ocen y_stanu_technicznego_doprowadzenie/194cc7e/2.html, pobrano 7.12.2014.

3. II SA/Kr 797/08 - Wyrok WSA w Krakowie z 2008-10-31, publikacja internetowa.: http://www.orzeczenia-nsa.pl/wyrok/ii-sa-kr-797-

08/pozwolenie_na_budowe_uzytkowanie_obiektu_lub_jego_czesci_wykonywanie_ro bot_budowlanych_innych_niz/174e39/7.html, pobrano 7.12.2014.

4. II SA/Gl 524/07 - Wyrok WSA w Gliwicach z 2007-11-30, publikacja internetowa.: http://orzeczenia.nsa.gov.pl/doc/FE292DDE1A, pobrano 7.12.2014.

5. II SA/Gd 425/12 - Wyrok WSA w Gdańsku z 2012-10-10, publikacja internetowa.: http://www.orzeczenia-nsa.pl/wyrok/ii-sa-gd-42512/budowlane_prawo/1840514.html pobrano 7.12.2014. 
6. Ustawa z dnia 24 czerwca 1994 r. o własności lokali, Dz.U. z $1994 \mathrm{Nr} 85$ poz. 388 ze zmianami.

7. Sokołowska M. Odpowiednie wydzielenie lokali w budynku pozwala dalej kwalifikować go jako jednorodzinny, ABC Wolters Kluwer business; publikacja internetowa $\mathrm{z}$ dnia 2.10.2013, http://www.budownictwo.abc.com.pl/czytaj/-/artykul/odpowiedniewydzielenie-lokali-w-budynku-pozwala-dalej-kwalifikowac-go-jakojednorodzinny, pobrano 1.12.2014.

8. Stanowisko Ministerstwa Infrastruktury i Rozwoju, Departament Mieszkalnictwa, z dnia 5 marca 2014 r. znak DM-Vpk-722-2/14 w sprawie wydzielania przez deweloperów wielu lokali mieszkalnych w budynkach jednorodzinnych.

9. IOSK 1653/11 - Wyrok NSA z 2012-02-08, publikacja internetowa.: http://www.orzeczenia-nsa.pl/wyrok/i-osk-1653-11/2c79ee4.html, pobrano 7.12.2014.

10. Kodeks Urbanistyczno - Budowlany, projekt przyjęty przez Komisję Kodyfikacyjną Prawa Budowlanego w dniu 16 kwietnia 2014 r., publikacja internetowa.:

http://www.mir.gov.pl/Budownictwo/Komisja_Kodyfikacyjna_Prawa_Budo wlanego/Documents/Kodeks_urbanistyczno_budowlany_projekt_podstawo wa_16_04_2014_jednolity.pdf, pobrano 5.08.2014.

11. Rządowy projekt ustawy o zmianie ustawy Prawo budowlane oraz niektórych innych ustaw, znak RM-10-56-13, Warszawa 26 sierpnia 2014, druk sejmowy nr 2710, publikacja internetowa.: http://www.sejm.gov.pl/Sejm7.nsf/druk.xsp?nr=2710, pobrano 5.11.2014.

12. Komunikat $\mathrm{nr} 33$ z posiedzenia Komisji Kodyfikacyjnej Prawa Bud. w dniu 29 stycznia 2014 r., publikacja internetowa.:

http://www.mir.gov.pl/Budownictwo/Komisja_Kodyfikacyjna_Prawa_Budo wlanego/Komunikaty_i_materialy/Documents/www_komunikat_nr_33A.pd f, pobrano 4.12.2014.

13. Sprawozdanie Podkomisji nadzwyczajnej do rozpatrzenia rządowego projektu ustawy o zmianie ustawy Prawo budowlane oraz niektórych innych ustaw /druk nr 2710/ z dnia 4 grudnia 2014 o rządowym projekcie ustawy o zmianie ustawy - Prawo budowlane oraz niektórych innych ustaw /druk nr 2710/, znak INF-0141- 4 -14, publikacja internetowa.: http://orka.sejm.gov.pl/opinie7.nsf/nazwa/spr_2710/\$file/spr_2710.pdf, pobrano 22.12.2014.

14. Ustawa $z$ dnia 27 marca 2003 r. o planowaniu i zagospodarowaniu przestrzennym, Dz. U. z 2012 r. poz. 647, 951, 1445, z 2013 r. poz. 21, 405, 1238, 1446, z 2014 r. poz. 379. 


\section{WYBRANE PROBLEMY STOSOWANIA PRAWA WE WSPÓŁCZESNYM PROCESIE ADAPTACJI I MODERNIZACJI OBIEKTÓW BUDOWLANYCH W POLSCE}

\section{Streszczenie}

Praca podejmuje, problematykę stosowania prawa dotyczącego procesu adaptacji i modernizacji obiektów budowlanych w Polsce, a także jego tworzenia. W ramach części pierwszej, praca koncentruje się na sposobach interpretacji kluczowej zasady Ustawy Prawo Budowlane, w myśl której roboty budowlane rozpocząć można jedynie na podstawie ostatecznej decyzji o pozwoleniu na budowę, z zastrzeżeniem artykułu 29 tej ustawy. Praca ukazuje także, jak prezentowana na przykładach interpretacja art. 28 i 29 ustawy, w powiązaniu z brakiem innych instrumentów kontroli prawnej, prowadzić może do realizacji zabudowy niezgodnej $\mathrm{z}$ przeznaczeniem funkcjonalnym, wynikającym $\mathrm{z}$ treści miejscowych planów zagospodarowania przestrzennego lub decyzji o WZ. Część druga pracy koncentruje się na trwających obecnie w kraju, pracach nowelizacyjnych nad ustawą Prawo budowlane, w kontekście zmian mogących wyeliminować negatywne zjawiska przedstawione $\mathrm{w}$ części pierwszej pracy. W ramach dokonanych analiz porównawczych potrzeb zmian ze zmianami proponowanymi obecnie przez ustawodawcę, praca wskazuje na potrzebę korekty zapisów słownika pojęć ustawy Prawo budowlane (art. 3) oraz zapisów ustawy o samodzielności lokali. Praca wskazuje też na głęboką potrzebę praktyki dobrego stosowania prawa, realizowanej jedynie na drodze tworzenia jednoznacznych i minimalizujących pole do interpretacji przepisów.

Słowa kluczowe: Prawo budowlane, interpretacja, budowa, przebudowa, samodzielność lokalu, zgłoszenie robót.

Prezentowane wyniki badań, zrealizowane w ramach tematu nr A3/2015/DS zostały sfinansowane z dotacji na naukę przyznanej przez Ministerstwo Nauki i Szkolnictwa Wyższego

Editor received the manuscript: 18.01 .2015 